\title{
The Possibility of Determining Osteoporosis by Analysing the Medical Images of the Cortical Bone
}

\author{
Mihails Kovalovs ${ }^{1}$, Aleksandrs Glazs ${ }^{2}$ \\ ${ }^{1,2}$ Riga Technical University
}

\begin{abstract}
This paper proposes a method of bone structure analysis that could be used to determine if a person has osteoporosis by analysing the cortical bone on medical images. Osteoporosis is a bone disease that leads to an increased risk of fracture. This method automatically extracts the cortical bone form medical images and measures its thickness. The proposed method was tested on medical images of healthy people and people with osteoporosis, to see if it could extract the cortical bone from both patient groups and to analyse the cortical bone thickness measurements.
\end{abstract}

Keywords - Cortical bone, medical images, osteoporosis, region of interest extraction.

\section{INTRODUCTION}

Bone structure analysis is needed to determine bone strength and assess the damage to the bone micro-architecture that appears due to such bone disease as osteoporosis (see Fig. 1). Bone structure analysis on a living person (in vivo) is easier and more effective to perform by using medical images. Medical images acquired by computed tomography are divided into slices. Traditionally, the medical image analysis is performed by a radiologist, who visually looks through all the two-dimensional images. Such an analysis is subjective and takes a considerable amount of time. To speed up the analysis and acquire reproducible measurements, it is necessary to use automatic medical image processing methods.

At present, osteoporosis is mostly diagnosed by measuring the bone mineral density (BMD), which is usually obtained using dual-energy $\mathrm{x}$-ray absorptiometry (DXA) [1]. DXA is a two-dimensional, projection-based radiographic technique that measures integral BMD of both cortical and trabecular bone. BMD only explains about $70 \%$ to $75 \%$ of the variance in bone strength [2], while the remaining variance is due to the cumulative and synergistic effect of other factors such as bone architecture, tissue composition and micro damage [3]-[5]. One of the important factors that contributes to bone fragility is the thinning of the cortical bone and increased cortical bone porosity [6].
Medical image analysis is a very topical issue; recently many new methods have been developed for various medical objects and tasks [7]-[9], as well as methods that are intended specifically for a bone structure analysis and osteoporosis [10]-[12]. Most existing medical image processing algorithms are manual or semi-automatic algorithms. Such algorithms often require a physician to intervene in the medical image segmentation process, to set or edit the segmentation parameters, or manually outline the segments. Such operations require technical knowledge that the physician might not have, and they also require extra time, which is not desirable if the physician has to see many patients.

Another disadvantage of the existing medical image segmentation methods is that they use images that were acquired using high resolution medical imaging devices [13], [14] that are not available in ordinary hospitals and diagnostic centres. The methods proposed in this paper were developed using the images that were acquired using computed tomography, because medical images acquired by means of this method are widely used in clinical practice when diagnosing patients.

The proposed method was described in detail in previous publications [15], [16]; it was also tested on medical images of people with osteoporosis to see whether it could be used to evaluate the changes in bone structure [17]. In this paper, the proposed method was tested on medical images of two patient groups - healthy people and people with osteoporosis. The main goal was to find out whether the proposed method could be used to determine whether the patient has osteoporosis by analysing the cortical bone thickness measurements.

\section{THE PROPOSED METHOD}

One of the main objectives was to develop a fully automatic algorithm that would not require input from the user. This is necessary in order to ease and speed up the job of the doctor, who will be working with the medical images. However, the user still has the option to change the main parameters of the algorithm in order to increase the precision of the segmentation algorithm for a specific patient. 


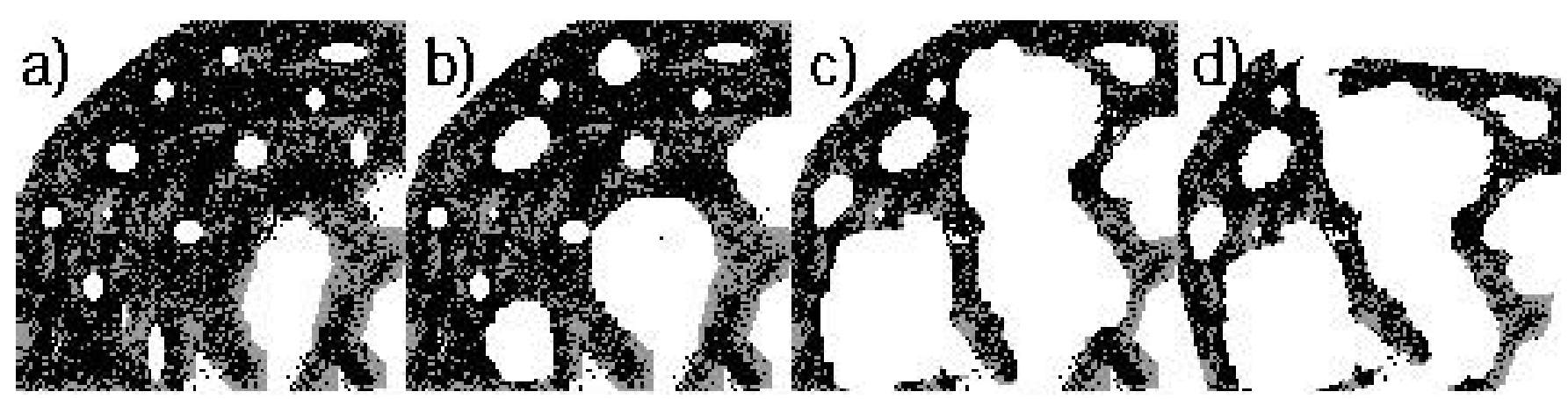

Fig. 1. The effects of osteoporosis on the cortical bone: a) normal, b) osteopenia, c) osteoporosis, d) severe osteoporosis.

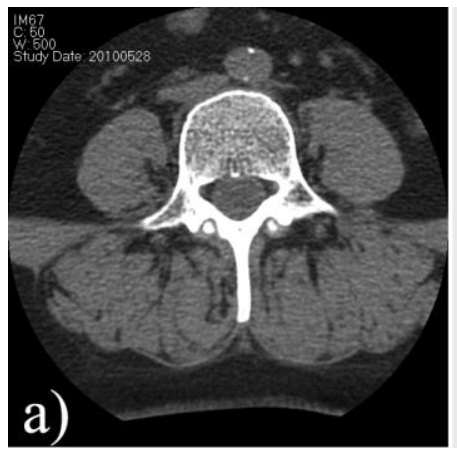

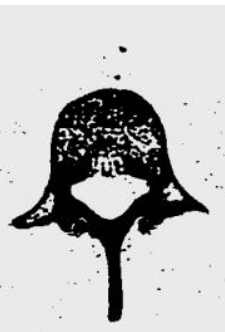

b)

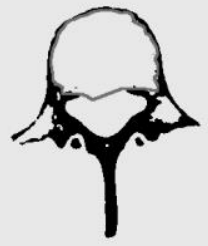

c)

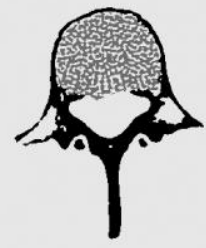

d)

Fig. 2. Bone structure extraction from medical images of human vertebra.

\section{A. Bone Structure Extraction}

Bone structure extraction consists of five steps:

1. A medical image (see Fig. 2a) is divided into segments, which could contain the cortical bone.

2. Segments created in the previous step are combined into clusters (see Fig. 2b).

3. Clusters are classified to find those clusters that contain the cortical bone and discard all other clusters.

4. A contour is created inside the cortical bone that adapts to the inner edges of the cortical bone (see Fig. 2c).

5. Trabecular bone is extracted from the inside of the previously created contour (see Fig. 2d).

The first three steps apply to the extraction of the cortical bone and the last two steps apply to the extraction of the trabecular bone.

\section{B. Cortical Bone Thickness Measurement}

The average thickness of the cortical bone is measured using the inner and outer contour of the cortical bone. The inner contour is created automatically during the bone structure extraction. The outer contour is created as a copy of the inner contour (see Fig. 3a), which then expands and shrinks until it perfectly describes the outer edge of the cortical bone (see Fig. 3b).

The average thickness of the cortical bone is measured as an average distance between the control points of the inner and outer contours (see Fig. 3c). In case of medical images of the vertebra, it is only necessary to measure the upper part of the cortical bone, where the control point's vector $y$ value is positive. That is done because the bottom part of the vertebral cortical bone contains growth (spinous and transverse process) that does not affect the average thickness of the cortical bone.
The average thickness $\left(T_{\mathrm{img}}\right)$ of the cortical bone on one medical image is calculated using the following formula:

$$
T_{\text {img }}=\frac{1}{n} \sum_{i=1}^{n} d_{i}
$$

where

$T_{\text {avg }}$ - the average thickness of the cortical bone on one image, pixels;

$d_{i}-$ the distance between a control point on the inner and outer contour, pixels;

$n$ - the amount of control points in the inner contour.

\section{Experiment}

A developed bone structure extraction algorithm was used to extract the cortical and trabecular bone from the medical images. The algorithm was tested on sets of medical images from two patient groups. The first group consisted of eight healthy patients aged 18 to 26 years, and the second group consisted of six patients with osteoporosis aged 55 to 86 years.

Before the extraction of the bone structure can begin, it is necessary to choose the value of the cortical bone density threshold. This threshold is used in the first step of the bone extraction algorithm to find the pixels that might contain the cortical bone on the medical image. The cortical bone threshold value is the only parameter that is set by the user. However, that is not always necessary, since it is usually assumed that the cortical bone density of healthy people is greater than $300 \mathrm{Hu}$. For people suffering from osteoporosis, cortical bone density is considerably lower. Therefore, in order to compare both patient groups, it is necessary to select the cortical bone threshold value that would suit both groups. 

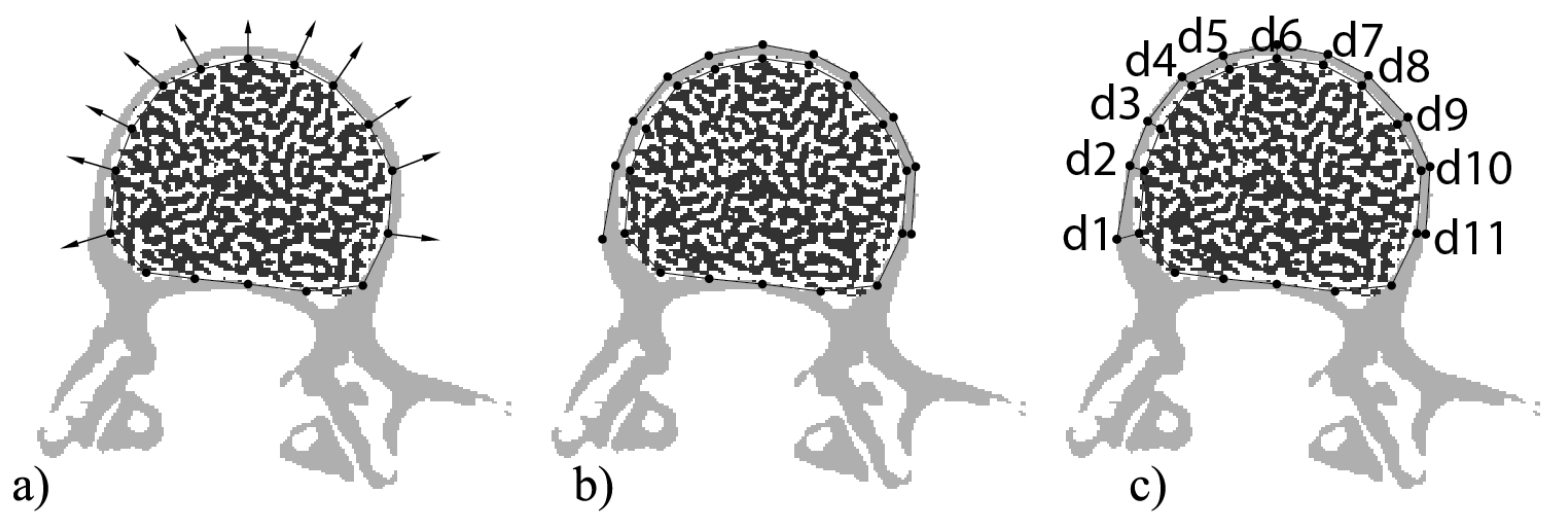

Fig. 3. Cortical bone thickness measurement, a) inner contour is expanded, b) inner and outer contour, c) distances between inner and outer contour.
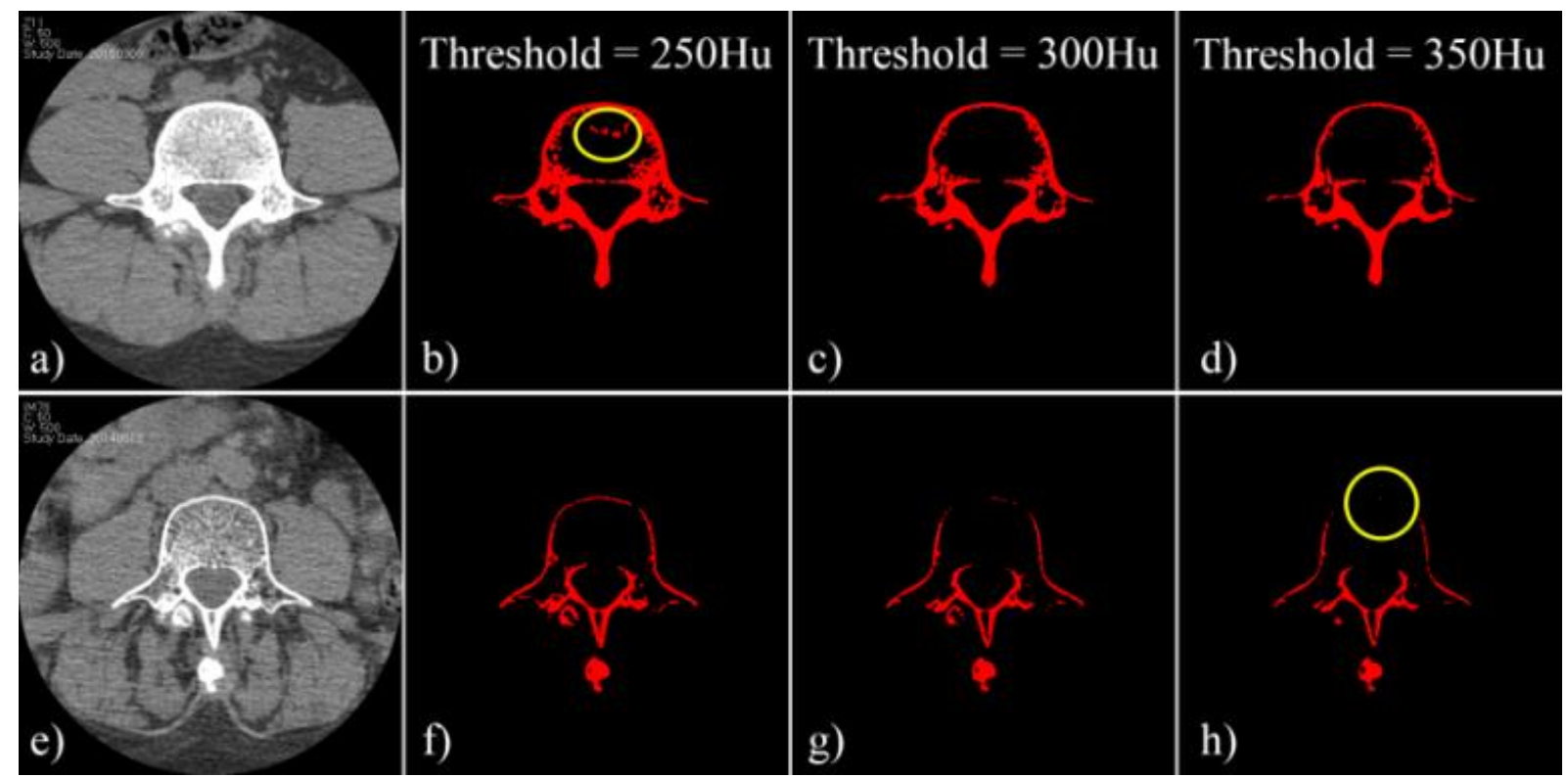

Fig. 4. Examples of extracted cortical bones, using different threshold values.

To select the appropriate threshold value, the developed bone extraction algorithm was applied to several medical images from both patient groups, using different threshold values. An example of the extracted bone structures can be seen in Fig. 4, where the top row contains the medical images of the healthy patients, and the bottom row contains the medical images of patients with osteoporosis.

Several threshold values were considered: from $250 \mathrm{Hu}$ up to $350 \mathrm{Hu}$. For healthy patients, the threshold of $250 \mathrm{Hu}$ was too small, because using this threshold value the cortical bone was not accurately extracted. Several objects, inside the cortical bone, were incorrectly assigned to the cortical bone. These objects are highlighted with a yellow circle in Fig. 4b. The best result for healthy patients was achieved using the threshold value of $350 \mathrm{Hu}$. For patients with osteoporosis, the threshold value of $350 \mathrm{Hu}$ is too high, because the extracted cortical bone had large holes, the upper part of the cortical bone almost completely disappeared, which is highlighted in figure $4 \mathrm{~h}$. The best result for patients with osteoporosis was achieved using the threshold value of $250 \mathrm{Hu}$. However, as previously stated, such a threshold does not work with healthy patients. The only threshold value that was capable of extracting the cortical bone for both patient groups was $300 \mathrm{Hu}$

The average thickness of the cortical bone was measured in all patients in order to verify that the proposed algorithm could be used to distinguish the healthy patients from patients with osteoporosis, based on their measurements. The average cortical bone thickness ( $\left.T_{\mathrm{avg}}\right)$ was calculated for each patient from all the measurements from their L4 vertebra images.

$$
T_{i m g}=\frac{1}{n} \sum_{i=1}^{n} T_{i},
$$

where $T_{\text {avg }}$ - average cortical bone thickness, pixels; $T_{i}$ - cortical bone thickness measurement on one medical image, pixels; $n$ - the amount of images that contain the L4 vertebra. 
TABLE I

Bone STRUCTURE MEASUREMENTS OF HEALTHY PATIENTS

\begin{tabular}{|c|c|c|}
\hline $\begin{array}{c}\text { Patient } \\
\text { number }\end{array}$ & $\begin{array}{c}\text { Age } \\
\text { (years) }\end{array}$ & $\begin{array}{c}\text { Cortical bone average } \\
\text { thickness (pixels) }\end{array}$ \\
\hline 1 & 25 & 4.333 \\
\hline 2 & 26 & 7.566 \\
\hline 3 & 18 & 4.252 \\
\hline 4 & 19 & 9.059 \\
\hline 5 & 22 & 7.344 \\
\hline 6 & 21 & 14.684 \\
\hline 7 & 24 & 30.572 \\
\hline 8 & 23 & 6.172 \\
\hline \multicolumn{2}{|c|}{ Average } \\
\hline
\end{tabular}

Table I shows the cortical bone average thickness and trabecular bone average density measurements of eight healthy patients. The developed bone structure extraction and analysis algorithms successfully managed to extract the bone structure and measure the cortical bone thickness trabecular bone density from the medical images of almost all eight healthy patients. The only exception, where the developed algorithms failed, was the medical images of the 7 th patient. This patient had a very high bone density and the chosen cortical bone density threshold was too small, because of that the developed algorithm incorrectly extracted some regions of the bone that could not belong to the cortical bone (see Fig. 5). The tissue density in this region was higher that the chosen cortical bone threshold value.

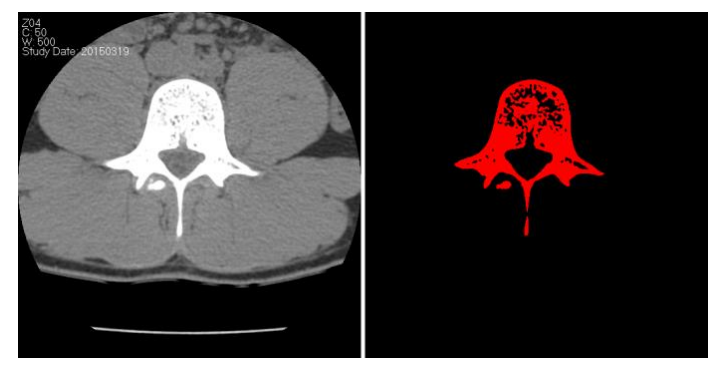

Fig. 5. The medical image and the extracted cortical bone of the 7 th patient.

It was decided to exclude the measurements of the 7 th patient from the average measurements of all patients. Otherwise, to correctly extract the bone structure of the 7 th patient it would be necessary to increase the cortical bone threshold value, but then it would be difficult to extract the bone structure from patients with osteoporosis, whose bone density was low.

TABLE II

Bone STRUCTURE MEASUREMENTS OF PATIENTS WITH OSTEOPOROSIS

\begin{tabular}{|c|c|c|}
\hline $\begin{array}{c}\text { Patient } \\
\text { number }\end{array}$ & $\begin{array}{c}\text { Age } \\
\text { (years) }\end{array}$ & $\begin{array}{c}\text { Cortical bone average } \\
\text { thickness (pixels) }\end{array}$ \\
\hline 1 & 56 & 5.306 \\
\hline 2 & 55 & 1.936 \\
\hline 3 & 79 & 2.431 \\
\hline
\end{tabular}

\begin{tabular}{|l|l|l|}
\hline 4 & 83 & 1.317 \\
\hline 5 & 75 & 1.474 \\
\hline 6 & 56 & 2.460 \\
\hline \multicolumn{2}{|c|}{ Average } & 2.487 \\
\hline
\end{tabular}

Table II shows the cortical bone average thickness and trabecular bone average density measurements of six patients with osteoporosis. The measurement results of all patients were roughly similar, with only one exception. The cortical bone average thickness of the 1st patient was significantly greater than that of other patients, because this patient had a tumour on the cortical bone (Fig. 6). Based on the results of the experiment, it can be concluded that the developed bone structure extraction algorithm is able to successfully extract the cortical and trabecular bone from both the healthy patients and patients with osteoporosis.

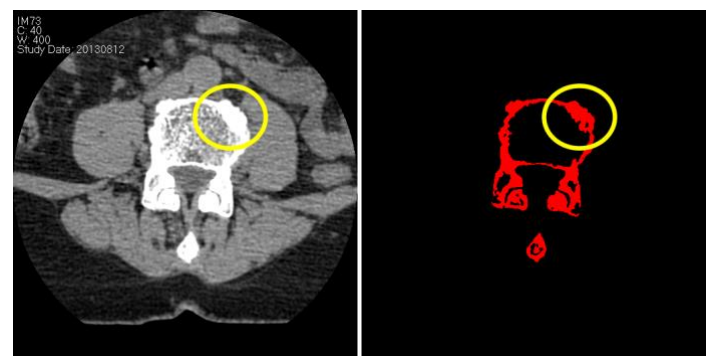

Fig. 6. The medical images of the 1 st patient showing the tumour on the cortical bone.

By comparing Tables I and II, it can be seen that the cortical bone average thickness measurements in healthy patients are significantly higher (almost 4 times higher) than that in patients with osteoporosis. However, the trabecular bone average density measurements are approximately the same for both patient groups. Based on the results of the experiment, it can be concluded that it is possible to distinguish the healthy patients from patients with osteoporosis on the basis of their cortical bone thickness measurements that are provided by the developed bone structure analysis algorithms.

\section{CONCLUSION}

The main objective was to develop methods, which could be used for a bone structure analysis, and to automatically evaluate changes in bone structure after a time period. The developed methods are capable of extracting the cortical and trabecular bones from medical images. The extraction process is fully automatic; however, the operator has the option of editing the main parameters, to increase the precision of the extraction algorithm.

New methods of evaluating the changes in bone structure have been developed. The developed methods can measure the cortical bone average thickness and the trabecular bone average density. The changes in bone structure can be evaluated by comparing the measurements that were performed on medical images taken at various time intervals. The developed bone structure analysis methods would be 
useful when treating patients with osteoporosis, where by analysing the changes in bone structure it would be possible to evaluate the effectiveness of the treatment plan.

\section{REFERENCES}

[1] J. E. Adams, "Dual-Energy X-Ray Absorptiometry", Radiology of Osteoporosis, Medical Radiology, Springer Berlin, 2008, pp. 105-124. http://dx.doi.org/10.1007/978-3-662-05235-8_6

[2] P. Ammann and R. Rizzoli, "Bone strength and its determinants," Osteoporosis International, Vol. 14, Issue 3 Supplement, 2003, pp. 13-18.

[3] B. R. McCreadie and S. A. Goldstein, "Biomechanics of Fracture: Is Bone Mineral Density Sufficient to Assess Risk?" J. of bone and mineral research, vol. 15, 2000, pp. 2305-2308. http://dx.doi.org/10.1359/jbmr.2000.15.12.2305

[4] F. W. Wehrli, P. K. Saha, B. R. Gomberg et al. "Role of magnetic resonance for assessing structure and function of trabecular bone," Topics in Magnetic Resonance Imaging, vol. 13, 2002. pp. 335-355. http://dx.doi.org/10.1097/00002142-200210000-00005

[5] T. Hildebrand, A. Laib, R. Muller et al. "Direct threedimensional morphometric analysis of human cancellous bone: microstructural data from spine, femur, iliac crest, and calcaneus," J. of bone and mineral research, vol. 14, 1999; pp. 1167-1174. http://dx.doi.org/10.1359/jbmr.1999.14.7.1167

[6] V. Bousson, F. Peyrin, C. Bergot, et al. "Cortical bone in the human femoral neck: three-dimensional appearance and porosity using synchrotron radiation," J. of Bone and Mineral Research, vol. 19, Issue 5, 2004, pp. 794-801. http://dx.doi.org/10.1359/JBMR.040124

[7] P. Dastidar, T. Heinonen, J. Numminen et al. "Semi-automatic segmentation of computed tomographic images in volumetric estimation of nasal airway," European Archives of Oto-Rhino-Laryngology, 1999, vol. 256, no. 4, pp. 192-198. http://dx.doi.org/10.1007/s004050050138

[8] B. van Ginneken, M. B. Stegmann, M. Loog, "Segmentation of anatomical structures in chest radiographs using supervised methods: a comparative study on a public database," Medical Image Analysis, vol. 10, Issue 1, February 2006, pp. 19-40. http://dx.doi.org/10.1016/j.media.2005.02.002

[9] A. J. Worth and D. N. Kennedy, "Segmentation of magnetic resonance brain images using analogue constraint satisfaction neural networks," Image and Vision Computing, vol. 12, Issue 6, July-August 1994, pp. 345-354. http://dx.doi.org/10.1016/0262-8856(94)90059-0

[10] S. Boutroy, M. L. Bouxsein, F. Munoz et al. "In vivo assessment of trabecular bone microarchitecture by highresolution peripheral quantitative computed tomography," The J. of clinical endocrinology and metabolism, vol. 90, 2005, pp. 6508-6515. http://dx.doi.org/10.1210/jc.2005-1258
[11] H. R. Buie, G. M. Campbell, R. J. Klinck, et al. "Automatic segmentation of cortical and trabecular compartments based on a dual threshold technique for in vivo micro-CT bone analysis," Bone, vol. 41, 2007, pp. 505-515. http://dx.doi.org/10.1016/j.bone.2007.07.007

[12] A. J. Burghardt, T. M. Link, S. Majumdar, "High-resolution Computed Tomography for Clinical Imaging of Bone Microarchitecture," Clinical orthopaedics and related research, vol. 469, 2011, pp. 2179-2193. http://dx.doi.org/10.1007/s11999-010-1766-x

[13] B. Hyun, D. C. Newitt, S. Majumdar, "Assessment of cortical bone structure using high-resolution magnetic resonance imaging," in Proc. 13th Scientific Meeting, Int. Society for Magnetic Resonance in Medicine, Miami, 7-13 May, 2005.

[14] R. Krug, A. J. Burghardt, S. Majumdar et al. "A High-Resolution Imaging Techniques for the Assessment of Osteoporosis," Radiologic Clinics of North America, vol. 48, 2010. pp. 601-621. http://dx.doi.org/10.1016/j.rcl.2010.02.015

[15] M. Kovaliovs and A. Glazs, "Medical Image Analysis to Determine the Effectiveness of Osteoporosis Treatment," Scientific J. of RTU Technologies of Computer Control, vol. 13, Riga: RTU, 2012, pp. 11-14.

[16] M. Kovaliovs and A. Glazs, "Trabecular bone segmentation by using an adaptive contour," Scientific Journal of RTU Technologies of Computer Control, vol. 14, Riga: RTU, 2013, pp. 6-11.

[17] M. Koval̨ovs and A. Glazs, "Automatic medical image analysis for measuring bone thickness and density," Conf. Biomedical Engineering Proc., Kaunas University of Technology, Kaunas, Lithuania, 2014, pp. 153-157.

Mihails Kovalovs was born in Riga, Latvia, on 7 September 1986. He is a $\mathrm{PhD}$ student at Riga Technical University, Faculty of Computer Science and Information Technology. He received the degree of Master of Technical Sciences from Riga Technical University in 2011.

E-mail: Mihails.Kovalovs@rtu.lv

Aleksandrs Glazs was born in Riga, Latvia, on 7 April 1939. He is a Professor at Riga Technical University, Faculty of Computer Science and Information Technology, Vice-Director of Institute of Computer Control, Automation and Computer Engineering, Head of Department of Image Processing and Computer Graphics. He received the degree of Candidate of Technical Sciences from Riga Polytechnic Institute in 1971 and the degree of Doctor of Technical Sciences (Dr. habil. sc. ing.) from the Russian Academy of Sciences in 1992. He has more than 100 scientific publications in different areas: pattern recognition, image processing, computer vision and computer graphics. A. Glazs is a full member of the Baltic Informatization Academy. E-mail: glaz@egle.cs.rtu.lv

\section{Mihails Kovaḷovs, Aleksandrs Glazs. Osteoporozes noteikšanas iespēja, analizējot kortikālā kaula medicīnas attēlus}

Dotajā darbā tiek aprakstīta kaulu medicīnas attēlu automātiskā analīzes metode, kur attēli tika iegūti ar datortomogrāfijas palīdzību, lai varētu noteikt osteoporozi pacientiem pēc kortikālā kaula biezuma mērijjumiem. Doto metodi var izmantot kaulu struktūras analīzei. Tas var būt lietderīgi ārstiem, kuri ārstē pacientus, kuriem ir osteoporoze, un kur ir nepieciešams analizēt izmainas kaulu struktūrā.

Šobrī̉ jau eksistē daudzas medicīnas attēlu analīzes metodes, taču liela dạ̧a no šīm metodēm ir pusautomātiskās un ir nepieciešama operatora iejaukšanās segmentācijas procesā, kas nozīmīgi palielina laiku, kas tiek patēerêts uz medicīnas attēla segmentāciju. Dotajā darbā piedāvātā metode ir pilnīgi automātiska un tajā tiek izmantoti medicīnas attēli, kas iegūti ar parastas datortomogrāfijas palīdzību.

Piedāvātā metode tika pārbaudīta uz pacientu medicīnas attēliem, kurus var sadalīt divās grupās: veselīgi pacienti un pacienti, kuriem ir osteoporoze. Izmantojot piedāvāto metodi, var automātiski izdalīt kortikālo kaulu un izmērīt kortikālā kaula vidējo biezumu pacientiem no abām grupām. Pēc kortikālā kaula biezuma mērījumu rezultātiem var viegli atšķirt veselīgos pacientus no pacientiem, kas slimo ar osteoporozi, jo vidējais kortikālā kaula biezums veselīgiem pacientiem vidēji ir gandrīz 4 reizes lielāks nekā pacientiem, kas slimo ar osteoporozi.

\section{Михаил Ковалёв, Александр Глаз. Возможность определения остеопороза по анализам медицинских изображений кортикальной кости} В данной работе описывается метод автоматического анализа медицинских изображений кости, полученных с помощью компьютерной томографии, для определения остеопороза у пациентов по измерениям толщины кортикальной кости. Данный метод может быть использован для анализа структуры кости, что может быть полезно для врачей, лечащих пациентов, больных остеопорозом, где необходимо анализировать изменения в структуре кости.

На данный момент уже существует множество методов анализа медицинских изображений, но большинство этих методов являются полуавтоматическими и требуют вмешательства оператора в процессе сегментации, что значительно увеличивает время, потраченное на сегментацию медицинского изображения. Предложенный в данной работе метод является полностью автоматическим и использует медицинские изображения, полученные с помощью обычной компьютерной томографии.

Предложенный метод проверялся на медицинских изображениях пациентов, которых можно разделить на две группы: здоровые пациенты и пациенты, больные остеопорозом. Предложенный метод сумел автоматически выделить кортикальную кость и измерить среднюю толщину кортикальной кости на медицинских изображениях пациентов из обоих групп. По результатам измерений толщины кортикальной кости можно легко отличить здоровых пациентов от больных остеопорозом, так как средняя толщина кортикальной кости у здоровых пациентов была в среднем почти в 4 раза больше, чем у пациентов, больных остеопорозом. 